\title{
Elmélet és gyakorlat ellentmondásossága a mérnöki etikában
}

\author{
É. BUJALOSNÉ KóCZÁN
}

Debreceni Egyetem Műszaki Kar, Műszaki Menedzsment és Vállalkozási Tanszék, beva@eng.unideb.hu

Abstract. Economy is the framework of the activities of technological managers. The function of an economy is substantially impact by behaviors of the persons are involved in the economy. Its function depends on how they follow rules of society and community. Reliability and order of an economy are created by right conducts of such participants of economy as technological managers. This paper analyses the complex relations of law, morality and economy.

\section{A témaválasztás indoklása}

Az előző konferencián a jogról, ez erkölcsről és a gazdaságról fejtettem ki a gondolataimat. A társadalmi létezésnek ezek a fontos területei egymással hárompólusos kapcsolatban léteznek, mert a jognak nemcsak az erkölccsel, hanem a gazdasággal is van kapcsolata, valamint fennáll az erkölcsnek a gazdaságra gyakorolt hatása is. Az elmúlt év óta sajnos nem nőtt, hanem rosszabbodott a normakövetési hajlandóság a magánélet, és a gazdaság szférájában is. A normaszegő magatartás olyan mértékűvé vált, hogy a mérnöktársadalom szakmai szervezetei is kezdtek ezzel a problémával foglalkozni, részben kamarai gyúléseken, részben konferenciákon, és az itt elhangzott gondolatokat igyekeztek szakmai újságokban is közzétenni, hogy a szakma szélesebb köre is értesüljön róluk. Ez mutatja azt, hogy jogosan találhatjuk ezt a témát ismét aktuálisnak. A felsőoktatásban, ahol a műszaki szakembereket képzik, a mérnöki etika és az üzleti etika tantárgy keretében kell megismertetni a leendő mérnökökkel azokat az ideális erkölcsi értékeket, amelyeket a mérnöki munka során tanúsítaniuk kellene, amennyiben jó mérnökök szeretnének lenni. Bár ők még mérnöki élettapasztalat híján vannak, a mindennapi valóságot ismerik annyira, hogy lássák: a gyakorlati élet valamint az elméleti elvek és értékek feszítő ellentmondásosságban vannak egymással. A gazdaságban tevékenykedők tudják, hogy a jog és az erkölcs a gazdaságban fontos szerepet kap, és a gazdasági hatékonyságot rontja, ha a normákat nem lehet, vagy nehéz követni a gazdasági életet meghatározó körülmények miatt. Ha pozitív változást szeretnénk elérni, akkor van értelme elemezni a szaketikai normákat, boncolgatni és alaposabban feltárni azokat a körülményeket, amelyek a gazdaságban tevékenykedő mérnököket cselekvéseik során arra ösztönzik, hogy inkább normaszegő magatartást tanúsítsanak, mint normakövetőt. A helyes normákat el kell sajátítani, belsővé tenni, vagyis elfogadni és akarni őket, mint pozitív cselekvési mintákat, majd nehéz körülmények között is meg kell találni azokat a helyes eszközöket, amelyekkel érvényesíthetők. Nemcsak a normarendszeren belül kell koherenciának és ellentmondás-mentességnek lennie, hanem a gyakorlati életben sem érezhet az 
egyén nagyfokú ellenérdekeltséget a normakövető magatartással szemben. A normakövetés ugyanis alapvető társadalmi érték és érdek. Jelenleg a hazai mérnöki erkölcsben a "kell" és a "van" között nagyfokú ellentmondásosság feszül, amit minél hamarabb mérsékelni kell. Ez érdeke az egyénnek is, (a tevékenykedő mérnöknek) és a társadalomnak is.

\section{A “jó” mérnök jellemzői}

Az erkölcsben a társadalom számára értékesnek tartott normák fogalmazódnak meg, mint követendő, helyes magatartásszabályok. Az erkölcsi normák jelentőségét tekintélyes közgazdászok is elismerik: „ha van megfelelő morál, akkor ott a viszonylag gyenge és sok hibás jogi keret és útját tévesztett gazdaságpolitika mellett is biztosan megjönnek a gazdasági eredmények, ahol pedig hiányzik a morál, semmilyen jog nem hozhat eredményeket" [1.] Különösen a műszaki elit, a mérnöktársadalom magatartására vonatkoztatható ez a megállapítás.

Egy konkrét társadalom erkölcse összetett. Ez érvényes egy szűkebb társadalmi csoport tagjaira is, tehát a mérnök társadalom tagjaira is. Közöttük is találunk vallásosakat, akik valláserkölcsi normákat követnek, és ateistákat, akik magánemberként világi erkölcsi normák szerint élnek. A világnézeti különbségeken kívül az erkölcsöt néhány általános sajátosság jellemzi. Ezek közül csak néhányat fogok most felsorolni. Az erkölcsben találunk magatartási fokozatokat, mert mindkét ember erkölcsösen viselkedhet, de az egyik személy nagyobb áldozatra készebb, mint a másik. Az alapvető erkölcs normák minden emberre egyaránt vonatkozó magatartási formák, de vannak olyan magatartások is, amelyeket csak különleges emberek tudnak tanúsítani. Az erkölcs pozitív és negatív erkölcsi vonásként elismeri és értékeli az emberek erkölcsi tulajdonságait, de nem tudja garantálni a betartásukat, hiszen nincs olyan apparátusa, amely biztosítaná a mindig erkölcsös viselkedést. Fontos sajátosság az is, hogy már a rossz szándék megléte is negatív értékítéletet von maga után; valamint az, hogy egyén felelőssége mellett más emberek, és a társadalom felelősségének kérdése is felvetődik benne. Eltérően a jogtól, a bűn itt nem évül el.

Azért alakították ki a foglalkozási etikák között a mérnöki etikát, hozzá az Mérnöki Etikai Kódexet, mert rájöttek, hogy az erkölcsösség nem csak önmagában való érték a társadalomban, hanem hasznot hozó érték is a gazdaságban. A kamarák hivatottak arra, hogy az alapvető normákat megfogalmazzák, és etikai-fegyelmi eljárásokat lefolytatva szankcionálják az erkölcstelen mérnöki magatartást. Az Etikai-fegyelmi Kódexben fogalmazódnak meg az általános normák, melyeket elolvashatunk Legeza László könyvében is. [2.]

A mérnök munkájával a társadalom anyagi jólétéhez kell, hogy hozzájáruljon. Magas szintű szaktudását a fenntartható fejlődés ügye mellett elkötelezve, a társadalom tagjainak életminőségét javítva kell hasznosítania. Ha ezt az értékteremtést szándékosan, vagy hanyagságból elmulasztja, gátolja, vagy károsítja, etikai vétséget követ el. Ilyen esetben a 2012. évi CLVII. törvény előírásai alapján - amely a jelenleg hatályos kamarai törvény,- a kamarának etikai fegyelmi eljárást kell lefolytatnia a normaszegő mérnökkel szemben.

A Kódex az „Alapvető elvek” elnevetésű első részben leszögezi azt az első alapelvet, hogy a hivatás gyakorlása közben minden másnál fontosabb feladat az emberek biztonságának, egészségének, 
jólétének, valamint a természeti környezet és az emberek javainak az ésszerű védelme. Ehhez a legfontosabb általános értékrendhez kapcsolva sorol fel, tehát konkretizál bizonyos mérnöki magatartásokat, amelyeket kötelezettségként kezel. Ezeket a viselkedéseket kell tehát a jó mérnöknek tanúsítania. Ha a mérnök szakmai döntését bárki oly módon változtatja meg, hogy emiatt az előbbi értékek veszélybe kerülnek, akkor járjon el az ügyben és értesítse az érintetteket, valamint a megfelelő szerveket. Csak olyan megbízást fogadjon el és teljesítsen, amelyek az érvényben lévő szabályozásnak megfelelnek, és biztonságosak. A természeti környezetbe csak körültekintően, mérnöki igényességgel és etikusan avatkozzon be. Tisztelje az elődök alkotásait, mint kulturális értékeket. A hivatali titkokat védje. Ne kerüljön semmilyen kapcsolatba olyan személlyel vagy szervezettel, akiről joggal feltételezhető az, hogy csalárd, tisztességtelen üzleti, szakmai tevékenységbe bonyolódott. A gazdaságossági szempontokat maximálisan érvényesítse munkája során. Az etikai vétséget jelentő ügyekben információt adjon, és múködjön együtt a Magyar Mérnöki Kamarával. Munkatársaival is mindig javíttassa ki az elkövetett hibákat.

Az alapelvek között a második alapelv arról szól, hogy a mérnök tevékenységében ne lépje túl saját illetékességének határait. Ezt úgy teheti meg, ha szakképesítésének, jogosultságának és gyakorlatának megfelelő megbízásokat vállal el; nem ír alá olyan tervet és dokumentációt, amelyben nem illetékes, illetve amely nem az ő irányítása és ellenőrzésével készült; illetve csak akkor ír alá, ha a részmunkákat is szakképzett és illetékes mérnök készítette és már aláírta.

A harmadik alapelv azt rögzíti, hogy a mérnök legyen tárgyilagos és ragaszkodjék az igazsághoz a szakmai követelmények teljesítése során, állásfoglalásaiban és az általa kiadott igazolásokban is. Ezek az elvek csak úgy tudnak érvényesülni, ha a mérnök kapcsolataiban nincs összeférhetetlenség, és nyilvánosak a hozzá kapcsolódó érdekviszonyok. Ha véleménynyilvánításai tényismereten, és tárgyi illetékességen alapulnak. Ha a mérnök törekszik véleményét széleskörű adatokra alapozni, és a rendelkezésére álló adatokat nem szándékosan szelektíven használja. Ha később is hajlandó az esetlegesen felmerülő új és fontos tények alapján módosítani a számításait és álláspontját Ha törekszik arra, hogy álláspontján egyértelműen fejtse ki, és ha ez nem lehetséges, akkor bemutatja ezek okait, és felvázolja az alternatívákat. Ha vita esetén sem elfogult, és eredményeinek hitelességét sem lehet megkérdőjelezni. Ha a részrehajlásra irányuló befolyásolási kísérleteket egyértelműen elutasítja, és nyilvánosságra hozza. Ha az önként, vagy felkérésre tett nyilatkozataiban korrekt, különösen akkor, ha a mérnöki tevékenységről, vagy munkatársa munkájáról nyilatkozik.

A negyedik alapelv szerint a mérnöknek mindenkor kifogástalan, elfogulatlan korrekt magatartást kell tanúsítania. A mérnöki magatartás akkor nevezhető korrektnek, ha a mérnök munkaadójának vagy megbízójának feltár minden általa ismert érdekellentétet. Ha ugyanazért a munkáért egyidejüleg több féltől nem fogad el díjazást. Ha más munkája után nem akar díjazásban részesülni. Ha nem tesz személyes előnyökért engedményeket, még akkor sem, ha ezzel saját állását veszélyezteti. Ha személyesen nem vesz részt az államot képviselve olyan döntésekben, amelyekből saját maga, vagy hozzátartozója anyagi előnyhöz juthat. Ha nem vállal olyan szakmai munkát, melynek elbírálásában tőle függő, vagy vele munkakapcsolatban lévő személyek járnak el. Ha nem fogad el megbízást olyan megbízótól, akinél saját kollégája is tevékenykedik. Ha vállalásait mindig teljesíti; ha szolgáltatási díjként a kamara által megfogalmazott ajánlott díjszabást kéri. 
Az ötödik alapelv azt tartalmazza, hogy a mérnöknek munkavállalási ügyekben kerülnie kell minden félrevezető cselekedetet. Ha tiszteletben tartja kollégája eredményeit; ha nem torzítja el a korábbi munkáihoz kapcsolódó felelősségét; ha megbízások elnyeréséhez nem kapcsol semmilyen pénzadományt, amivel a külvilág előtt azt a képzetet kelti, hogy képes befolyásolni a döntéseket; és semmilyen formában nem kapcsolódik olyan pályázatokhoz, amelyekkel kapcsolatban joggal feltételezhető az, hogy az esélyegyenlőség nem biztosított, nincs tiszta verseny.

A Kódex második része a „Szakmai kötelezettségek” elnevezésű rész. Ebben a részben 8 darab paragrafusba szedve részletesen található meg az alapelvekhez köthető helyes mérnöki magatartás leírása. Különösen a szakmai függetlenség, a magas műszaki színvonalú és biztonságos javak létrehozásával közérdek szolgálata, a kamarával való szoros együttműködés, a szakmai hitelrontásnak és a közvélemény félrevezetésének az elkerülése, a szakmai titkok és szellemi alkotások védelme, korrupciótól való tartózkodás, és a gazdasági hatékonyságra való törekvés van ebben a részben kívánatos magatartásformaként ismét hangsúlyozva.

A jó mérnököt az elvek szintjén már el tudjuk képzelni, hiszen csodálatosan összeszedi az Etikai Kódex a helyes és követendő magatartásszabályokat. Ezekhez még kapcsolhatjuk azokat az értékeket is, amelyeket a mérnöki etika tantárgy keretében hangsúlyozunk ki. Nemcsak Legeza László, hanem néhai kollégánk Nagy Géza is sokat tett azért, hogy a helyes mérnöki magatartás elvei kimunkálódjanak. Ő képviselte azt a mérnöki etikában azóta széles egyetértésben vallott álláspontot, hogy „a technikával kapcsolatos döntések, intézkedések-mindig etikai döntések is-, hiszen jelentős következményei lehetnek az emberi életre".[3.] Az ipari forradalom óta lezajló óriási technikai fejlődés egyrészt lehetőséget adott az emberi élet gazdagabb kibontakoztatására, egy nagyobb boldogságot lehetővé tevő életminőség elérésére, másrészt ez a fejlődés új problémákat is okozott, amelyek közül sok probléma globális szintűvé vált. A technikát pedig a mérnök hozza létre és működteti, ezért neki nemcsak a problémák előidézésében, hanem a megoldásukban is fokozott szerepük van. Ez egy növekvő, és egyre magasabb szintű erkölcsi felelősséget jelent a mérnöki szakma számára. Csak megismételni tudom azt, amit már egyszer írtam: „A mérnök munkájával egyaránt tud az emberiség jótevője is lenni, de képes rettenetes következményű károkat is okozni a természetben és embertársai életében, testi épségében, egészségében."[4.] Ugyanakkor nélküle nincs se gazdasági növekedés, se életminőség javulás, se fenntartható fejlődés sem! A mérnöki erkölcs értékrendjébe ezért került bele a fokozott tervezői felelősség, a környezet és a jövő generációk iránti fokozott elkötelezettség gondolata a fenntartható fejlődés formájában, az energiafelhasználás erkölcsi kérdéseinek hangsúlyosabbá válása, a műszaki alkotások kockázatainak szélesebb körű értelmezése és kiszámítása, a mérnöki felelősség összetettségének (dologi, büntetőjogi, erkölcsi) hangsúlyozása. Ezért lett fontos a mérnök munkahelyi vezetőként tanúsított helyes magatartás, a munkanélküliség csökkentésében játszott szerepének kimondása, és az értelmiségi felelősségének hangsúlyozása.

Ez tehát az elméleti értékrend, amelyet egy jó mérnöknek a mindennapi munkája során tetteiben meg érvényesítenie kellene, vagyis követnie „kellene”. 


\section{A mérnöki erkölcs gyakorlati körülményei}

A gyakorlati életben - ami a mérnökök számára a gazdaság szférájában végzett ipari termelőmunkát jelenti,- szembesülniük kell azzal a kihívással, hogy szakmájuk helyes viselkedési szabályait milyen nehéz betartani. A mérnöki munka presztízsének nagyfokú csökkenésében az egyik ok a mérnöki erkölcs nagymértékű erodálódása. Ez még akkor is így van, ha egyes mérnökök a mérnöketikai kérdésekkel való foglalkozást butaságnak tartják, és fennhangon kikérik maguknak, mondván, hogy "már pedig ők erkölcsösek!” Nagyon igaza volt Pattantyús Ábrahám Géza műegyetemi professzornak abban, hogy a jó mérnök fejében a szaktudás és az általános múveltség csak 25-25\%-ot kell jelentsen, és a többi, tehát a maradék 50\%, az erkölcsi erő kell legyen. Azt, ahogyan 25 évvel a rendszerváltás után mérnökeink tevékenykednek, már nem lehet a szocialista erkölcsre fogni, ezek már a kapitalizmus bizonyos szintjének rovására írandók. Elég a gyakorlati életből vett néhány kritikai kérdést feltenni ahhoz, hogy lássuk azt, a valóság messze áll az elméleti értékektől.

A gyakorlati életből feltett kérdéseimet egy másik tanulmányomból idézem: "Meddig lehet elmenni az üzleti titok védelmében akkor, amikor a mérnök védi vállalata, munkahelye belső életének részleteit és estleges titkait? Meddig lehet elmenni a munkavállalók életének, testi épségének a veszélyeztetésében költségtakarékosságra hivatkozva? Meddig lehet támogatni a munkáltatót,- aki inkább hajlandó bírságot fizetni, mint környezetkímélő, szabálykövető megoldásokat alkalmazni, - a káros melléktermékek elhelyezésekor? Meddig lehet fő szempont az egyéni jövedelemszerzés maximálása olyan áron is, mint kenőpénz elfogadása? Meddig lehet elveszteni az önálló gondolkodást és elvtelenül behódolni a politikának, sőt a pártpolitikának? Meddig lehet a rövidtávra születő, kényszerhelyzetben hozott gazdasági döntések súlyos hatásait elhallgatva „csak szakemberként” végezni a mérnöki munkát? Meddig lehet felmentenie a mérnöknek magát a felelősség alól, arra hivatkozva, hogy „csak fogaskerék vagyok!”? Meddig lehet etikátlan összefonódásban, vagy érdekellentétben, fóállás melletti magánérdekeltségekben egyszerre gyakorolni a mérnöki munkát? Meddig lehet olyan mérnök kamarai tag, aki nem gátolta meg munkahelyén a technológiai fegyelem súlyos megsértését?" [5.

A gazdaság erkölcsi állapotát egyszerre befolyásolja is, és mutatja is, a mérnöktársadalom erkölcsi állapota. A mérnöki erkölcs alapvető meghatározó eleme a mindennapokban a mérnöki felelősségtudat szintje. Szükség van azonban arra is, hogy követhető és szakmailag megalapozott jogszabályokhoz kelljen a mérnöknek alkalmazkodnia, és az államnak kiszámítható gazdaságpolitikája legyen. Hogyan is néz ki jogrendszerünk ebből az aspektusból vizsgálva? A jogalkotás időben mindig mögötte kullog a gazdasági változásnak, amikor viszont politikai szándékok szerint akarja gyorsan és gyökeresen átformálni a gazdasági viszonyokat, akkor az „ötletezgetések” miatt a gazdaság szétzilálódik, hiába igyekszik az állam növekvő jogalkotási hévvel beavatkozni. A válságok időszakát nem rövidíti, hanem hosszabbítja az agyonszabályozó, gazdasági viselkedéseket növekvő mértékben kriminalizáló állam. Friedman szerint: „Az ösztönzést kiváltó magas adók, a gazdasági kezdeményezéseket megfojtó szabályozások, még a legfejlettebb gazdaságokban is veszélyeztetik a növekedést, amely elválaszthatatlan az innovációtól és a kreativitástól." [6.] Hazánkban a jogalkotó hatalom a piaci verseny tisztaságát maga torzítja el, és ezzel morálisan is problémássá teszi a gazdaság működését. Ez a gazdasági vezetőkből az érdekérvényesítés erkölcstelen formáit hívja elő a vállalati talpon maradás érdekében. Bővebben ezekkel a negatív vezetői magatartásokkal a vezetéselmélet 
foglalkozik.[7.] Az állam tehát a gazdaságirányítás területén maga is súlyosbítja a társadalom morális válságát. Amikor a jogi norma és a társadalmi érdek nincs összhangban, akkor a gazdaság szereplője számára a jogalkalmazásban egyre nagyobb szerepet fog kapni a mérlegelés. Normális viszonyok között, a gazdaságban a növekvő jogi szabályozást ellensúlyozzák azzal, hogy a társadalom az állami intézményrendszeren keresztül egyre jobban gondoskodik a tagjairól, így a jogi és morális követelmények közötti ellentét egyre tompul. Könnyebbé válik a jogalanyok számára a jogkövető magatartás, ha azt látják, hogy az állami intervenciók - például pályázatok elbírálásakor - alapvető szempontja az, hogy a gazdaság szereplői jövedelmüket ne a konkurenciaharc, a korrupció, stb., hanem a méltányos elosztás elvei alapján szerezzék meg. A méltányos elosztás akkor érvényesül, ha a szabályozó hatalom kompromisszummal alkalmazkodik a közösségi preferenciákhoz, tehát a többség által elfogadott optimális vagyon és jövedelemelosztási elképzelésekhez. A méltányos elosztás így erkölcsi szempontként bekerül a gazdaság belső szempontrendszerébe, ami pozitív erkölcsi magatartásokat vált ki a gazdaság szereplőiből, és így elősegíti a fejlődést és a növekedést. Ez érvényes a mérnökök magatartására is. A jogkövető magatartás akkor is gyengül, ha a társadalomban súlyos lesz a bizalomvesztés. A fiatal demokráciákban, nagy gazdasági visszaesés idején, a fokozott bizalomvesztés miatt a gazdaságban a jogellenes magatartások különböző formái mindennaposakká válnak, aminek egyik oka a korrupció. A korrupció, nemcsak azért problematikus, mert erkölcstelen magatartások kapcsolódnak hozzá, hanem azért is, mert a tulajdon nem megfelelő állami védelme, a közösség elől még a meglévő erőforrásokat is elvonja, így csökkenti a bajok orvoslásának az esélyét és fokozza a bizalomvesztést. Ördögi spirál képződik, amiből a kiutat sem társadalmi, sem egyéni szinten nem könnyű megtalálni. Az gazdaság szereplői számára nem a tevékenységük eredményeként előálló jövedelem abszolút nagysága a fontos, hanem a jövedelemhez jutás kiszámíthatósága, és az, hogy a reáljövedelmükkel milyen életminőséget tudnak maguknak biztosítani. Amíg gazdasági növekedés van, addig az emberek elégedettek. Ha a gazdasági növekedés leáll, akkor előbb -utóbb szétfoszlik az eddigi életszínvonal érzete, sőt az eddigi életminőség érzete is. Elfogadhatjuk Friedman álláspontját, hogy az egyének érzelmileg mindezt a csökkenést erősebb érzésekkel élik meg, mint magát a növekedést. Mindez hatással van az erkölcseikre is![8.] Hiszen nem fognak bízni a jövőbe, sőt sokan egyenesen kilátástalannak tartják, ugyanakkor a mindennapi bizonytalanság, és kiszámíthatatlanság viszonyai között kellene erkölcsösen tevékenykedniük és élniük. Úgy érzik, hogy a pillanatnyi megélhetéshez nem a normakövetés, a korrektség, a szakmai tisztesség, a megbízhatóság, a nyitottság, a szorgalmas és tisztességes munka, hanem valami más szükséges! Már a vallásos világnézetű mérnökök közül sem viselkednek sokan a protestáns etika szabályai szerint, „amely a kemény munkát, a szorgalmat, a türelmet, a fegyelmezettséget és a kötelezettségek betartását biztosító kötelességtudatot, tehát a pozitív erkölcsi magatartást várja el az embertől”[9.]. Ebből arra következtethetünk, hogy azok a valláserkölcsi normák, amelyek eddig morális örökségünk legfontosabb normáit adták, elveszítettek erejüket. Ezt érzi a pápa is, aki a valláserkölcsi normákat igyekszik erősíteni, az emberek esélyegyenlőséggel kapcsolatos morális igénye miatt. Hiszen ha az életminőségben lévő egyenlőtlenségek ellenére, a saját emberi méltóságom megéléséhez biztosítottak számomra az alapvető javak, akkor érdekeltté válok egy modern és sikeres gazdaság létrehozásában és fenntartásában, ami a társadalmi stabilitást, és az emberek jó közérzetét is biztosítja. 
A fejlett gazdaságokban a vállalat etikus viselkedése nagyobb profitot eredményez, mint a tisztességtelen versenyben képződő profit. Az állami megrendelések elnyerésekor is előnyt jelent egy normális gazdaságban, ha a cég betartja az üzleti etika szabályait. A közvetlen hasznosság mellett létezik közvetett hasznosság is, amikor az etikai kódexeknek az alkalmazottakra vonatkozó normáit érvényesítik a cégnél a múködésük során. Ezek hosszabb távon biztosítják a vállalat rentábilis működését. A hazai ipari cégek esetében ez még csak elérendő álom, különösen az építőiparban. Vannak azonban olyan etikai normák is,- ráadásul ezek a legmagasabb értéket jelentő etikai normák-, amelyek követése profitcsökkenéssel jár. Ilyen terület a természeti értékek megőrzése. Hiszen tönkretehetjük az embernek, mint biológiai lénynek a természeti létfeltételeit! $\mathrm{Az}$ iparban tevékenykedő mérnök tehet a legtöbbet azért, hogy védje a természeti életfeltételeinket, ugyanakkor a javak előállítása is az ő feladata. Sen szerint a létező kapitalizmus etikája erősen korlátozott a környezetvédelem területén, mert a piac szereplői előszeretettel alkalmazzák a környezetszennyezést, amit ő tisztességtelen eszközökkel elért gazdasági előnynek tart. [10.] Ezzel a vélekedéssel teljes mértékben egyetérthetünk, ez hazánkban fokozottan így van.

\section{Megoldási javaslatok az erkölcsös mérnöki viselkedés eléréséhez}

A mérnöki erkölcs javítása nemcsak a külső körülmények megváltoztatását igényli, hanem az egyén oldaláról is sokat kell tenni érte. A kettőt szinte egyszerre kell csinálni.

Milyen változtatások szükségesek az állam működésében? Sokfélék! Ilyen változtatásnak minősülnek a szakmailag megalapozott jogi normák, és a széleskörű érdekegyeztetés. Szükséges lenne a kiszámíthatóságra, a jó gazdaságpolitikára, a bizalomerősítésre, és hatékony lépésekre a korrupció visszaszorítására. De a biztonságos banki működés, és a jól működő állami közhivatalok is szükségesek lennének. Tudjuk, hogy a hatósági ügyintézés az iparban is nagy szerepet kap. Mégsem lehet megalapozottan hinnünk abban, hogy azok az elképzelések, amelyeket az építésügyi engedélyezési rendszer átalakításával kapcsolatban a Magyar Mérnöki Kamara 2015. március 20-án megtartott workshop ülésén megfogalmaztak, elősegíti az építőiparban tevékenykedő mérnökök erkölcsének javulását. A tervezetről szóló újságcikk szerint, [11.] a kialakítandó komplex beruházási kódex és engedélyezési rendszer azt a célt szolgálná, hogy egy pontos és tartós jogi környezeten, valamint világos és egyértelmű felelősségi rendszeren alapuljon, továbbá az ügyfélbarát, szolgáltatástípusú ügyintézés mellett megfelelően garantálja a minőség biztosításához szükséges feltételeket. Mikor és hogyan lesz hazánkban ilyen jogi környezet, ilyen hatósági ügyintézés, és ilyen minőségi munkát végző mérnöktársadalom? Jelenleg a szűkebb felelősségek sem állnak meg, nemhogy egy emelt szintű "egymásba fonódó" felelősségi rendszer!

Nem a rendszer gyökeres átalakítása, hanem a szereplők lecserélése, vagy a magatartásuk megváltoztatása hozhat pozitív eredményt. Az olyan a mérnök, aki úgy érzi, hogy nem elég jó, nem kell, hogy a pályán maradjon. "Egy építész, akinek el kell ismernie, hogy kollégája szakmailag jó, sőt sokkal jobb, mint ő valaha is lehetne, abbahagyhatja az építészetet és vállalhat más mesterséget..”vélekedik Hare.[12.] Szerinte ezt azért kellene megtennie, mert ha komolyan veszi a mérnöketikai értékeket, akkor szeretné elkerülni azt, hogy frusztrált és korrupt legyen. Az embernek tisztába kell lennie saját képességeivel és személyiségjegyeivel, tehát megfelelő szintű önértékeléssel kell rendelkeznie. 
Képesnek kell lennie egyéni érdekeit összeegyeztetni a társadalmi értékekkel. Ezt az etika mérsékelt egoizmusnak nevezi. Az nem is minősül erkölcsös cselekedetnek, amit csak az önszeretet és az önérdek vezérel. Csak az olyan magatartás erkölcsös, amelyben a másik ember iránti szeretet, a jó tevés igénye is benne van, és hiányzik belőle az ártó, és káros szándék. Be kell látnunk, hogy a társadalmi lét értékesnek tartott normái, tehát az erkölcsi normák, magasabb rendű értékek, mint az ember pillanatnyi céljai, vágyai. Hiszen ha a pozitív célok, a megfelelően kiválasztott eszközök, és a kötelességek teljesítése összhangba van, csak akkor jöhet létre a társadalom számára az üdvözítő következmény. Ekkor lesz a mérnöki munka eredménye a társadalom számára nem átok, hanem áldás.

A mérnöknek a kötelezettségeit teljesítenie kell, - mert a fokozott felelősséggel járó, de súlyos kockázatokat is hordozó munkájában - a felelősségre vonás alól csak így tud mentesülni. A kötelezettség erkölcsi kötelezettséget is jelent, tehát a helyes viselkedést. A morál, vagyis az erkölcsös magatartás tanúsítása értelmi és érzelmi elemeken is nyugszik. "Az emberek késztetései és szükségletei arra viszik őket, hogy társuljanak, értelmük és tapasztalatuk viszont arra tanítja őket, hogy a társulás lehetetlen, ha nem követnek szabályokat, és nincsenek tekintettel a másik birtokára”.[13.] „Bár az erkölcs a társadalomban élő egyén számára a kívánatos jó, ugyanakkor felülmúlja az egyént, hiszen az nem akarhatja, és nem kívánhatja a társadalmat anélkül, hogy valamennyire erőszakot ne követne el saját egyéni természetén." [14.] A magyar mérnök, a jó 25 éve tartó társadalmi és gazdasági átalakulás időszaka alatt megelégelte azt, hogy a közösségi érdekre való állandó hivatkozás propagandáját tartsa fontosabb vezérelvnek cselekvéseiben, és nem pedig az egyéni érdekét. Már nem fontos neki, hogy erkölcsös mérnöki munkával tiszteletet ébresszen maga iránt. Vagy ha fontos is neki, nem képes ezért tényleges áldozatot hozni. Gyakran cselekszik úgy, hogy elméletben ugyan az általános szabályt tiszteletben tartja, de a gyakorlatban előny húz az összes kivételből. Ilyenkor azt gondolja, „hogy némi igazságtalanság vagy hűtlenség a nélkül növeli jelentősen vagyonát, hogy a társadalom egységében és szövetségében komoly törést okozna”.[14.] A szociálpszichológia talán segít megérteni ezt a magatartást. A társas befolyásolás, tehát az, hogy hogyan gyakorolnak az emberek egymás vélekedésére és viselkedésére hatást, abból indul ki, „hogy az individualitás illetve a konformitással társult értékek közötti feszültség állapotában élünk,”[15.] A konformitás, tehát amikor véleményünket, vagy viselkedésünket egy másik egyén vagy társadalmi csoport valódi vagy vélt nyomása következtében változtatjuk meg, nagy szerepet tölthet be abban a folyamatban, hogy megváltozzon a magatartás. A konformitásnak 3 formája van. Az egyik formája a behódolás, amikor engedelmeskedünk egy olyan hatalomnak, amely jutalmaz, vagy büntet. Ez lehet politikai hatalom, de lehet a kamara is. A másik forma az azonosulás, amikor valaki más vonzerővel arra inspirál, hogy olyan legyek, mint ő. A harmadik formája az internalizáció, amikor igazságosságra és hitelességre törekszem, és találok olyan személyt, akinek azért fogadom el a véleményét, mert megbízhatónak és hozzáértőnek találom. Azért fontos az, hogy csak magas szintű tudás és szorgalom alapján kapjon valaki mérnöki oklevelet és jogosultságokat, mert a magas önértékeléssel bírók kevésbé hajlamosak engedni az olyan csoportnyomásnak, melyek tagjai erkölcsileg problémás értékeket vallanak. Nehéz az egyéni tudatban előálló, az elmélet és a gyakorlat közötti ellentmondásosságot értelmesen feloldani, és a kellemetlen dolgokkal együtt élni. Feloldásként az önigazolás, az agresszivitás és a frusztráció, és a közöny eszközeivel él az ember. Pedig a reménytelenség viszonyait kellene megváltoztatnia, és a másik legyőzése helyett, - hiszen a siker 
számára egyet jelent a győzelemmel- az együttműködést kellene fokoznia, a felelősségtudatot növelni, a humánumot és az empátiát erősítenie a cselekvéseiben. Vissza kell térni egy másik alternatívához, amikor értjük és érezzük a társadalmi lény mivoltunkat.

\section{Összegzés}

A tisztességes versengés, a korrekt együttműködés nemcsak a mérnöki munkában, hanem a társadalmi élet minden területén javítja az emberek életérzését, és a növekvő boldogság mellett a fejlődést is elősegíti. Ha erős a kölcsönös egymásrautaltság érzése, a gazdasági, és az őket kísérő erkölcsi válságok is könnyebben leküzdhetők. Az attitűdváltozásoknak nem a behódolási, vagy az azonosulási

konformitási formák szoktak az erős okai lenni, hanem az, amikor az ember elhiteti magával, hogy az előző attitűdjei tévesek voltak. Egy jó kamara, és egy jó felsőoktatási képzés adhat a meggyőzéshez kezdőlépéseket. De azt is tisztázni kellene, hogy milyen társadalomban akarunk élni, és képesek vagyunk-e ezért cselekedni is. Mert ha nem, akkor az erkölcsi elvek és a tényleges cselekvés morális tartalma között egy idő után még óriásibb szakadék fog tátongani. Mindenkinek rá kell ébrednie a helyzet tarthatatlanságára.!

\section{Hivatkozások}

[1] S. Kopátsy (1993), Gazdasági jog- gazdasági morál in: Magyar Tudomány Akadémiai Kiadó és Nyomdai Vállalat Bp. 8. szám. 977. o.

[2] L. Legeza (2004), Mérnöki etika ,Akadémia -Mikes Kiadó Bp, 89-104. o.

[3] G. Nagy (1997), A mérnök és etikája, Kereskedelmi és Hitelbank Rt. Universitás Alapítványa Debrecen, 110.

[4] É. Bujalosné Kóczán (2014), Mérnöketikai értekezés a mérnök környezettudatos energiafelhasználási magatartásáról, Környezettudatos energiatermelés és felhasználás III. Konferencia Kiadvány Debrecen, 258. o. ISBN 978-963-7064-31-9

[5] É. Bujalosné Kóczán (2010), Paradigmaváltás a mérnökképzésben?(A mérnök szerepe az egészséges környezethez való alkotmányos jogunk érvényesülésében), Műszaki tudomány az Észak-alföldi Régióban 2010. Konferencia Kiadvány Debrecen, 144. o. ISBN 978-963-706423-4

[6] B. M. Friedman (2010), Jólét és erkölcsösség, Napvilág Kiadó Bp., 411.

[7] J. Roóz (2001), Vezetésmódszertan, Jegyzet Perfekt Kiadó Bp.

[8] B. M. Friedman (2010), Jólét és erkölcsösség, Napvilág Kiadó Bp., 411.

[9] M. Weber (1982), A protestáns etika és a kapitalizmus szelleme, Gondolat Kiadó Bp.

[10] A. Sen (2003), A fejlődés mint szabadság, Európa Kiadó, Bp., 401. 
[11] Mérnökújság XXII.évf.4. szám (2015), Hogyan egyszerüsítsünk együtt? 2015. áprilisi szám 11-13. o.

[12] R. M. Hare (1981), A „consensus” argumentuma ford, Lónyai Mária in: Tények és értékek Gondolat kiadó, Bp.

[13] D. Hume (2003), Tanulmány az erkölcs alapelveiröl, Osiris Kiadó Bp., 129.

[14] É. Durkheim (1978), A társadalmi tények magyarázatához, Válogatott tanulmányok Közgazdasági és Jogi Kiadó Bp., 166.

[15] D. Hume (2003), Tanulmány az erkölcs alapelveirôl, Osiris Kiadó, Bp.

[16] E. Aronson (1992), A társas lény, Közgazdasági és Jogi Kiadó, Bp. 53. 